\title{
A Comparative Analysis of the Outcomes of Carotid Stenting and Ca- rotid Endarterectomy in the Management of Carotid Stenosis
}

\author{
Hasan I. Fadel Saad ${ }^{1 *}$, Mustafa Noom ${ }^{2}$, Khalid Shnab ${ }^{3}$ and Abdel Magid El Osta ${ }^{4}$

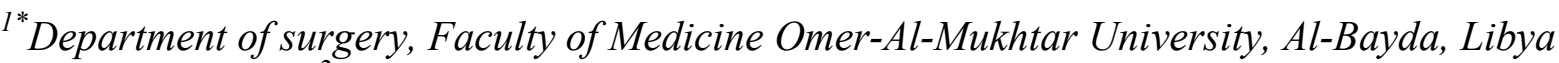 \\ ${ }^{2}$ Department of Vascular Surgery, BMC, Tripoli, Libya \\ ${ }^{3}$ Department of Surgery, Faculty of Medicine, Musrata University, Libya \\ ${ }^{4}$ Department of Surgery, Faculty of Medicine, Tripoli University, Libya
}

Received: 24 September 2019/ Accepted: 30 December 2019

Doi: https://doi.org/10.54172/mjsc.v34i4.134

\begin{abstract}
Carotid Stenosis is an important cause of stroke (20\%) which is associated with high morbidity and mortality rates. The management is mainly by surgery or carotid stenting. This study reviews 3 years of experience and the outcomes in the treatment of carotid stenosis by the two methods. The study aimed to evaluate and compare the outcomes of both procedures during a $3 \mathrm{yr}$ period at a vascular Surgery department of the Cisanello Hospital. 302 pts were retrospectively analyzed; $151 \mathrm{pts}$ assigned for each procedure. The average intervention time was significantly higher for the CEA group O.R: 0.556; 95\% C.I; 0.349- 0.886, P: 0.014 but technical successes were achieved in $100 \%$ of CEA pts, whereas were achieved in $91.39 \%$ of the CAS group. The periprocedural stroke was nonsignificant between the two procedures. The Periprocedural TIA were show significant difference with more incidences in CAS pts [O.R: 7.292, 95\% C.I; 1.150- 45.856, P: 0.032 ] but almost all pts improved. The cranial nerve injuries were a specific complication of CEA [11.9\%]. The recurrent stenosis was seen only in CAS pts [2.9\%] with O.R: $0.493,95 \%$ C.I; 0.1042.345 , P: 0.410 . Both procedures are effective and comparable in outcomes in the management of carotid Stenosis.
\end{abstract}

Keywords: Stroke; carotid stenosis; Carotid endarterectomy (CEA); carotid artery stenting (CAS)

\section{INTRODUCTION}

Carotid artery stenosis due to atherosclerosis is a common cause of strokes, which is responsible for around $20 \%$ of strokes in the adult population (Linfante et al., 2009). Surgical intervention to relieve atherosclerotic stenosis of the carotid arteries was first successfully performed by Dr. Michael DeBakey in 1953 at the Methodist Hospital in Houston, TX [Debakey Bio].The first case to be recorded in the medical literature was in The Lancet in 1954 (Eastcott et al., 1954). The role of carotid endarterectomy (CEA) for the treatment of atherosclerotic carotid bifurcation disease is now well established (Hobson et al., 1993). (CEA) is one of the most common vascular surgical procedures, and more (CEA)s are now being performed than at any time in the history of the operation (Ouriel et al., 2004; Tu et al., 1998). In the last few years, carotid artery stenting (CAS) has emerged as a possible alternative to (CEA) for the management of carotid artery stenosis (Narins \& Illig, 2006; Ricotta \& Malgor, 2008). The supporters of CAS underline the less invasive nature of the procedure, which enables its application in high-risk patients, the shorter in-hospital stay, and the reduction in wound complications and cranial nerve injury (Narins \& Illig, 2006; Ricotta \& Malgor, 2008). The results of three major European studies into the treatment of symptomatic stenosis- Endarterectomy versus Angio-

*Corresponding Author: Hasan I. Fadel Saad Hasanfadeel70@gmail.com, Department of surgery, Faculty of Medicine Omer-Al-Mukhtar University, Al-Bayda, Libya. 
plasty in Patients with Symptomatic Severe Carotid Stenosis (EVA-3S); Stent-Protected Angioplasty versus Carotid Endarterectomy (SPACE); International Carotid Stenting Study (ICSS) - showed that stenting was more hazardous than endarterectomy for the outcomes of stroke and death during the periprocedural period (30 days), and on longer-term follow-up (Eckstein et al., 2008; Ederle et al., 2010; Mas et al., 2008). In contrast, the North American Carotid Revascularization Endarterectomy vs Stenting Trial (CREST) demonstrated equivalent (non-significant) rates of stroke, myocardial infarction, and death in its stenting and endarterectomy groups in the periprocedural period, and at 4 years (Brott et al., 2010). The aim of this study is to evaluate and compare the outcomes of CEA with CAS in Cisanello Hospital in the period 2005 to 2008 .

\section{MATERIALS AND METHODS}

Records and a database were reviewed at the U.O of Vascular Surgery of the Cisanello Hospitals [Pisa/ Italy] during a 3 year period from June 2005 to December 2008. A total of 986 patients underwent carotid Stenosis management, invasively by an open surgical technique called carotid endarterectomy (CEA) which included most of the cases [835 (84.68\%)] pts, and by a less invasive method called carotid stenting (CAS) which included 151 pts $(15.31 \%)$. In the view to compare the outcomes of both procedures; we prefer to select a representative random sample from a surgical group, equal to the CAS group which was done with the help of the vascular surgery team in the unit for easy comparison and calculation. 302 cases treated with the two techniques, [151] for each, were collected and retrospectively analyzed. Information obtained included the demographic, clinical presentations of patients undergoing the two procedures, and the characteristics for the two types of intervention; in terms of duration, hospital stay, and successful technical and postoperative outcomes for the two procedures (Table 1).
Statistical analysis: The percentages of cases in each group were calculated and the effectiveness of the intervention was expressed as odds ratios and all data are presented with $95 \%$ confidence intervals with $\mathrm{P}$ values, accepting a significance level equal to $\alpha=0.05$.

\section{RESULTS}

Of 986 patients who were managed for carotid Stenosis by both CEA and CAS performed between June 2005 and December 2008, the medical records of 302 patients were assessed, in whom 151 underwent surgery and 151 an endovascular procedure. This selection was random for CEA pts and all cases who underwent CAS were included in the review. The $68.9 \%$ of the 302 patients examined were male (208 patients), and $31.1 \%$ were female (94 patients), forming a male to female ratio nearly 2:1 (Table 1). The distribution of sex along each procedure (CAS and CEA groups) are homogeneous for age and sex. The average age of all cases is $72.2( \pm 7.4)$ yrs. Apart from smoking which shows Significant differences between the two types of management [(CEA: $86(57.0 \%)$ vs. CAS: 51 (33.8\%), O.R: 0.385, 95\%C.I: $0.242-0.614 ; \mathrm{p}<0.05)]$. All previous data with other risk factors and associated cardiac and peripheral arterial diseases[PAD] were comparable, and no significant differences in both groups selected for study (Table 1) $245(81.12 \%)$ of them were asymptomatic, and the remainder $57(18.87 \%)$ of cases were symptomatic. The symptomatic group of pts form $(29.2 \%)$ and $(8.7 \%)$ for CEA and CAS respectively with O.R: 0.229 ; 95\% C.I: 0.119 $0.443, \mathrm{p}<0.05)$ which reveal significant difference between the two management options. Among the 14 symptomatic patients in the CEA group, $(9.2 \%)$ had a previous stroke, 28 (18.5\%) had had a TIA, amaurosis $2(1.4 \%)$. Among the 13 symptomatic (8.7\%) pts in the CAS group two pts gave a history of previous stroke $(1.4 \%)$, and 11 pts $(7.3 \%)$ had had TIA. The main cerebral symptom is TIA, The average incidence of TIA in this collection 39 
$(12.9 \%)$; most of these cases were in surgical the group (18.5\%) and $1.3 \%$ for CAS pts with an odds ratio 0.059 and 95\%C.I: 0.015 to 0.229 ; with a highly significant difference between the two treatments in the study. The history of previous stroke forming about $(5.3 \%)$ of all cases in the study which were seen much more in CEA pts than CAS pts [14 (9.2\%)] and [2 (1.3\%)] respectively O.R: $0.131 ; 95 \%$ C.I $0.033-0.529$, p.value: 0.002 significantly high in the group that underwent surgical treatment. The main indications for CAS procedure were as follows: restenosis in 16 cases $(10.6 \%)$, (irradiated, previous surgery, high Stenosis) in 7 $(4.6 \%)$ cases, and high surgical risk in 128 $(84 \%)$.

The operative and postoperative outcomes are summarized in (Table 2). The average duration of the intervention is $70 \mathrm{~min}( \pm 21)$ and $49( \pm$ 15) for CEA and CAS respectively with O.R: 0.556; 95\% C.I; 0.349- 0.886, P: 0.014 significantly high for the group that underwent surgical treatment. But the technical success was $100 \%$ for CEA, and $91.4 \%$ for CAS with $\mathrm{P}=$ 0.001 , which is also significantly high with the surgical treatment. Whereas in $13(8.6 \%)$ cases; the procedure failed because of anatomical problems causing impossible cannulation of the common carotid artery (String type III in 6 cases, excessive angulations of the aortic arch in 7 cases). The average postoperative hospital stay was significantly greater in the CAS group as compared to CEA [2.3 days (range 2-5) [2.3 ( $0.6)]$ for CEA and 1.7 days (range 1-24) [1.7 ( \pm 2.6), $\mathrm{p}<0.05)$.] for CAS. Postoperatively, the periprocedural central neurological complications occurred more with CAS pts [10 (6.7\%)]. The incidences of periprocedural stroke were $0[0 \%]$ and $3(1.9 \%)$ for CEA and CAS respectively, with nonsignificant P: 0.082 . The stroke occurred before placing the stent in one case and at the end of the procedure in 2 cases. The periprocedural TIAs were $1(0.7 \%)$ for CEA and $7(4.6 \%)$ for CAS with significant differ- ence [O.R: 7.292, 95\% C.I; 1.150- 45.856, P: 0.032].

The TIAs occurred within 3 hrs of the procedure in 4 cases and within $12 \mathrm{hrs}$ in 3 cases. 18 cases $(11.9 \%)$ of the cranial nerve injuries were recorded only in the CEA group: 9 patients reported dysphonia (50.0\%), dysphagia 6 $(33.3 \%), 3$ had difficulty moving the shoulder ipsilateral to the intervention $(16.7 \%)$. Of this group, 16 patient's symptoms were transient with spontaneous regression; in 2 cases, rehabilitation therapy was necessary, with complete recovery in 12 months. 40 patients $(28.8 \%)$ reported sensory disturbances on the surgical wound which resolved spontaneously. The procedural MI was only seen in CEA group, forming an incidence of $0.7 \%$ in this study sample. The incidence of hematomas of the surgical neck wound or at the groins [as a part of CAS technique] was more in the surgical group pts $(2.6 \%)$ and (1.4\%) respectively, with O.R: 0.493 ; 95\% C.I; 0.104- 2.345, P: 0.410, was not significantly different between the two treatments groups. The 4 cases have required re-exploration for the hematoma on neck incisions, and one of the two femoral access complications required surgery $(0.7 \%)$.

Recurrent stenosis was seen only in the CAS group in this collection; from about $2.9 \%$ with O.R: 0.493 , 95\% C.I; 0.104- 2.345, P: 0.410 . The four cases of restenosis were high-grade and required new endovascular treatment. There was no perioperative mortality related to the procedure in both groups. But on long-term follow-up [the mean follow-up after discharge was 22 months (range 1-43 months)] there were deaths in both groups $12(8.6 \%)$ [From 139 who attended or contacted by telephone] and $10(7.1 \%)$ of 141 for CEA and CAS respectively with O.R: 0.822 , 95\% C.I; 0.351 1.923, P: 0.658 with no significant difference between the treatment groups and the deaths were unrelated to the procedures. 
Table:(1). Demographic and clinical characteristics of patients subjected to a CAS and CEA in Cisanello Hospital, Pisa, 2005-2008.

\begin{tabular}{|c|c|c|c|c|c|c|c|}
\hline \multicolumn{2}{|l|}{ characteristics } & $\begin{array}{c}\text { total } \\
\mathrm{N}=302 \\
(100 \%)\end{array}$ & $\begin{array}{c}\text { CEA } \\
N=151 \\
(100 \%) \\
\end{array}$ & $\begin{array}{c}\text { CAS } \\
\mathrm{N}=151 \\
(100 \%) \\
\end{array}$ & $\begin{array}{l}\text { Odds } \\
\text { ratio }\end{array}$ & C.I & $P$ value \\
\hline \multirow{2}{*}{ sex } & male & $208(68.9 \%)$ & $108(71.5 \%)$ & $100(66.2 \%)$ & 4.9248 & $\begin{array}{l}3.021- \\
8.026\end{array}$ & 0.000 \\
\hline & female & $94(31.1 \%)$ & $43(28.5 \%)$ & $51(33.8 \%)$ & 1.281 & $\begin{array}{l}0.787- \\
2.084\end{array}$ & 0.321 \\
\hline \multicolumn{2}{|c|}{ Average age in years } & $72.2( \pm 7.4)$ & $72.9( \pm 7.9)$ & $72.1( \pm 6.8)$ & --- & --- & 0.346 \\
\hline \multirow{5}{*}{ Risk factors } & Dyslipidemia & $144(47.7 \%)$ & $75(49.7 \%)$ & $69(45.7 \%)$ & 0.853 & $\begin{array}{l}0.543- \\
1.339\end{array}$ & 0.490 \\
\hline & hypertension & $233(77.1 \%)$ & $116(76.8 \%)$ & $117(77.5 \%)$ & 1.038 & $\begin{array}{l}0.609- \\
1.771\end{array}$ & 0.891 \\
\hline & Diabetes m & $82(27.1 \%)$ & $42(27.8 \%)$ & $40(26.5 \%)$ & 0.935 & $\begin{array}{c}0.564- \\
1.550 \\
\end{array}$ & 0.796 \\
\hline & Cigarette smoking & $137(45.4 \%)$ & $86(57.0 \%)$ & $51(33.8 \%)$ & 0.385 & $\begin{array}{l}0.242- \\
0.614\end{array}$ & $0.000^{*}$ \\
\hline & $\begin{array}{l}\text { Renal insufficien- } \\
\text { cy }\end{array}$ & $17(5.6 \%)$ & $10(6.6 \%)$ & $7(4.6 \%)$ & 0.685 & $\begin{array}{c}0.262- \\
1.793\end{array}$ & 0.455 \\
\hline \multirow{2}{*}{$\begin{array}{l}\text { Associated pa- } \\
\text { thology }\end{array}$} & PAD & $42(13.9 \%)$ & $22(14.6 \%)$ & $20(13.3)$ & 0.895 & $\begin{array}{c}0.470- \\
1.707\end{array}$ & 0.740 \\
\hline & $\begin{array}{l}\text { Previous cardio- } \\
\text { vascular surgery }\end{array}$ & $65(21.5 \%)$ & $29(19.2 \%)$ & $36(23.8 \%)$ & 1.317 & $\begin{array}{l}0.761- \\
2.278 \\
\end{array}$ & 0.328 \\
\hline \multirow{5}{*}{$\begin{array}{l}\text { Cerebro } \\
\text { Vascular } \\
\text { symptoms }\end{array}$} & Asymptomatic & $245(81.1 \%)$ & $107(70.8 \%)$ & $138(91.3 \%)$ & 4.365 & $\begin{array}{l}2.255- \\
8.438\end{array}$ & $0.000^{*}$ \\
\hline & symptomatic & $57(18.9 \%)$ & $44(29.2 \%)$ & $13(8.7 \%)$ & 0.229 & $\begin{array}{l}0.119- \\
0.443\end{array}$ & 0.000 \\
\hline & stroke & $16(5.3 \%)$ & $14(9.2 \%)$ & $2(1.3 \%)$ & 0.131 & $\begin{array}{c}0.033- \\
0.529\end{array}$ & 0.002 \\
\hline & TIA & $39(12.9 \%)$ & $28(18.5 \%)$ & $2(1.3 \%)$ & 0.059 & $\begin{array}{c}0.015- \\
0.229\end{array}$ & 0.000 \\
\hline & Amaurosis & $2(0.6 \%)$ & $2(1.3 \%)$ & $0(0.0 \%)$ & 0.000 & $\begin{array}{c}0.000- \\
1.917\end{array}$ & 0.157 \\
\hline
\end{tabular}

C.I: confidence interval; PAD: Peripheral arterial disease; TIA: transient ischemic attack; O.R: odds ratio; C.I: confidence interval.

Table (2). Overall operative and post-operative results

\begin{tabular}{|c|c|c|c|c|c|c|}
\hline \multirow{2}{*}{\multicolumn{2}{|c|}{ characteristics }} & CEA & CAS & \multirow{2}{*}{ O.R } & \multirow{2}{*}{ 95\% C.I } & \multirow{2}{*}{$\mathrm{p}$ - value } \\
\hline & & [151 pts] & {$[151 \mathrm{pts}]$} & & & \\
\hline \multicolumn{2}{|c|}{$\begin{array}{l}\text { the average duration of the intervention } \\
\text { [min] }\end{array}$} & $70( \pm 21)$ & $49( \pm 15)$ & 0.556 & $0.349-0.886$ & $\begin{array}{l}0.014 \\
(\mathrm{p}<0.05)\end{array}$ \\
\hline \multicolumn{2}{|c|}{ technical success } & $151[100 \%]$ & $138(91.4 \%)$ & 0.000 & $0.000-0.273$ & $\begin{array}{l}0.001 \\
(\mathrm{p}<0.05)\end{array}$ \\
\hline \multirow{3}{*}{$\begin{array}{l}\text { neurological } \\
\text { complications }\end{array}$} & Periprocedural stroke & $0[0 \%]$ & $3(1.9 \%)$ & & & 0.082 \\
\hline & Periprocedural TIA & $1(0.7 \%)$ & $7(4.6 \%)$ & 7.292 & $\begin{array}{l}1.150- \\
45.856\end{array}$ & 0.032 \\
\hline & cranial nerve palsy & 18 cases $(11.9 \%)$ & $0[0 \%]$ & 0.000 & $0.000-0.190$ & 0.000 \\
\hline procedural MI & & $1(0.7 \%)$ & $0[0 \%]$ & & & 0.317 \\
\hline Haematomas & & $4(2.6 \%)$ & $2(1.4 \%)$ & 0.493 & $0.104-2.345$ & 0.410 \\
\hline recurrent stenosis & & $0[0 \%]$ & $4(2.9 \%)$ & 0.493 & $0.104-2.345$ & 0.410 \\
\hline & Perioperative death & $0[0 \%]$ & $0[0 \%]$ & & & 1.000 \\
\hline mortality & $\begin{array}{l}\text { Long-term non peri- } \\
\text { operative death }\end{array}$ & $\begin{array}{l}12 \\
(8.6 \%) / 139 \\
\end{array}$ & $\begin{array}{l}10 \\
(7.1 \%) / 141 \\
\end{array}$ & 0.822 & $\begin{array}{l}0.351- \\
1.923 \\
\end{array}$ & $\mathrm{p}=0.658$ \\
\hline
\end{tabular}




\section{DISCUSSION}

Carotid stenosis is one of the most common causes of stroke all over the world. And The treatment of carotid stenosis, therefore, lies in decreasing the risk of stroke or stroke-related deaths (van der Vaart et al., 2008). The CEA has been shown to reduce the overall risk for stroke and death compared with medical treatment in patients with relevant carotid artery stenosis, both with symptoms (Cina et al., 2000), and without symptoms (Chambers et al., 2000). CEA also carries a risk of stroke, sometimes disabling or fatal, and of myocardial infarction since many patients with carotid artery stenosis also have coronary artery disease (Endovascular versus surgical treatment (CAVATAS), 2001). Carotid stenting is a recent innovation started a decade ago where it is now competing for the surgical treatment of carotid Stenosis. Although it's less invasive than operative management, it may carry a higher risk of complications. In general; the asymptomatic cases have a lower procedural and periprocedural stroke or death rate with better results in both the short and long term. The selection criteria for selecting asymptomatic carotid artery Stenosis pts for surgery or stenting in this analysis was the stenosis equal to or greater than $70 \%$ and for symptomatic carotid artery stenosis, equal to or greater than $60 \%$. In the largest trial of asymptomatic subjects [asymptomatic carotid surgery trial (ACST)], the perioperative risk of stroke or death was $3.1 \%$, and after 5years, stroke risk was 3.8 vs. $11 \%$ for best medical therapy, i.e. 16 CE's were needed to prevent one stroke in 5 years (Halliday et al., 2004).

In our study; most of the cases where asymptomatic forming $81.1 \%$ of all cases, whereas the symptomatic cases forming $18.87 \%$. A recent meta-analysis of randomised controlled trials reported an increased risk of stroke or death within 30 days of carotid artery stenting compared with carotid endarterectomy (Ederle et al., 2009). This was similar to our result where the periprocedural central neurological complications such as stroke and TIA were more significant within the CAS group than the CEA group. In addition, a newer large observational study (A. Sidawy et al., 2009) and a multicenter randomized controlled trial (Committee, 2009) found a higher periprocedural $(<30$ days) incidence of stroke with carotid artery stenting compared with carotid endarterectomy. Based on these trials (Barnett et al., 1998); an acceptable upper limit of perioperative rate for stroke or death has been determined to be around 3\% for asymptomatic patients and 6\% for patients with symptoms. And as compared to our analysis, the average incidence of periprocedural stroke $1.9 \%$ happened only in CAS pts, not in CEA pts. And the incidence of perioperative death was $0 \%$ for both groups. And in several clinical trials, the 30-day incidence of heart attack, stroke, or death was significantly higher with stenting than with endarterectomy ( $9.6 \%$ vs. $3.9 \%$ ) (A. N. Sidawy et al., 2009). The procedural incidence of MI in our study was $0.7 \%$ only in CEA pts. The reported incidence of postoperative cranial nerve palsies after carotid endarterectomy varies from 1 to $30 \%$ (Organ et al., 2008).

The usual injuries occur in the vagus nerve and its branches, for example, the superior laryngeal, and recurrent laryngeal nerves, also, the hypoglossal nerve, spinal accessory nerve, marginal mandibular and transverse cutaneous nerve of the neck. The injuries varied from neuropraxia, axontemesis, and neurotemesis. Most of these injuries due to traction type injuries. Even though most of the cranial nerve neuropathies are transient, about 4\% persist over several months and about $0.5 \%$ are permanent (Cunningham et al., 2004). In comparison to our research; the incidence of cranial nerve injuries was $11.9 \%$ of all cases from CEA group pts. All pts improved over a period of time. The incidence of recurrent restenosis following CEA was found to be $6-14 \%$, which equates to an average annual restenosis or occlusion rate of $1.5-4.5 \%$ (Horrocks, 2000). And 
compared to our results; the incidence of the restenosis was $(2.9 \%)$ and was only with CAS pts. The comorbidities are the major risk factors with carotid endarterectomy. Carotid artery stenting outcomes are mainly influenced by the anatomy of local vessels and both factors have to be considered in treatment decision making (Bates et al., 2007). From this review; we noted that the CAS procedure is a less invasive procedure compared to CEA procedures with shorter duration of intervention and less postoperative hospital stay with no cranial nerve injuries which are recorded only in surgical group pts apart from TIA which occurred more with this procedure where pts mostly recover spontaneously over a period of time.

\section{CONCLUSION}

From this review, we conclude that both procedures are effective and comparable in outcomes in the management of carotid Stenosis. The CAS results are favorable especially if it used in selected cases as shown in Carotid Stenting Guidelines Committee: recommended indications and contraindications for carotid artery stenting (CAS) (Carotid Stenting Guidelines Committee, 2009).

\section{ETHICS}

All data was given by the head of the vascular department of the Cisanello Hospitals during the training period for conducting research regarding the Topic. The authors declare that they have no competing interests.

\section{REFERENCES}

Barnett, H. J., Taylor, D. W., Eliasziw, M., Fox, A. J., Ferguson, G. G., Haynes, R. B., Rankin, R. N., Clagett, G. P., Hachinski, V. C., \& Sackett, D. L. (1998). Benefit of carotid endarterectomy in patients with symptomatic moderate or severe stenosis .New England journal of medicine, 339(20), 1415-1425 .
Bates, E. R., Babb, J. D., Casey, D. E., Cates, C. U., Duckwiler, G. R., Feldman, T. E., Gray, W. A., Ouriel, K., Peterson, E. D., \& Rosenfield, K. (2007). ACCF/SCAI/SVMB/SIR/ASITN 2007 clinical expert consensus document on carotid stenting: a report of the American College of Cardiology foundation task force on clinical expert consensus documents (ACCF/SCAI/SVMB/SIR/ASITN clinical expert consensus document committee on carotid stenting). Journal of the American College of Cardiology, 49(1), 126-170.

Brott, T. G., Hobson, R. W., Howard, G., Roubin, G. S., Clark, W. M., Brooks, W., Mackey, A., Hill, M. D., Leimgruber, P. P., \& Sheffet, A. J. (2010). Stenting versus endarterectomy for treatment of carotid-artery stenosis. New England journal of medicine, 363(1), 11-23 .

Chambers, B., You, R., \& Donnan, G. (2000). Carotid endarterectomy for asymptomatic carotid stenosis (Cochrane review). la: Cochrane Library, Issue 4, 2002. Update Software .

Cina, C ‘.Clase, C., \& Haynes, R. (2000). Carotid endarterectomy for symptomatic carotid stenosis (Cochrane Review). The Cochrane Library, 4 .

Committee, C. S. G. (2009). Guidelines for patient selection and performance of carotid artery stenting. Journal of Medical Imaging and Radiation Oncology, 53(6), 538-545.

Cunningham, E. J., Bond, R., Mayberg, M. R., Warlow, C. P., \& Rothwell, P. M. (2004). Risk of persistent cranial nerve injury after carotid endarterectomy. 
Journal of neurosurgery, 101(3), 445448 .

Eastcott, H. H. G., Pickering, G. W., \& Rob, C. G. (1954). Reconstruction of internal carotid artery in a patient with intermittent attacks of hemiplegia. The Lancet, 264(6846), 994-996 .

Eckstein, H.-H., Ringleb, P., Allenberg, J.-R., Berger, J., Fraedrich, G., Hacke, W., Hennerici, M., Stingele, R., Fiehler, J., \& Zeumer, H. (2008). Results of the Stent-Protected Angioplasty versus Carotid Endarterectomy (SPACE) study to treat symptomatic stenoses at 2 years: a multinational, prospective, randomised trial. The Lancet Neurology, 7(10), 893-902 .

Ederle, J., Dobson, J., Featherstone, R., Bonati, L., van der Worp, H., de Borst, G., Lo, T., Gaines, P., Dorman, P., \& Macdonald, S. (2010). International Carotid Stenting Study investigators: Carotid artery stenting compared with endarterectomy in patients with symptomatic carotid stenosis (International Carotid Stenting Study): an interim analysis of a randomised controlled trial. Lancet, 375(9719), 985-997.

Ederle, J. r., Featherstone, R. L., \& Brown, M . M. (2009). Randomized controlled trials comparing endarterectomy and endovascular treatment for carotid artery stenosis: a Cochrane systematic review. Stroke, 40(4), 1373-1380 .

Halliday, A., Mansfield, A., \& MARRO, J. (2004). PETO C, PETO R, POTTER], THOMAS D; MRC Asymptomatic Carotid Surgery Trial (ACST) Collaborative Group. Prevention of disabling and fatal strokes by successful carotid endarterectomy in patients without recent neurological symptoms: randomised controlled trial. Lancet, $363,1491-150.2$

Hobson, R. W., Weiss, D. G., Fields, W. S., Goldstone, J., Moore, W. S., Towne, J. B., Wright, C. B., \& Group, V. A. C. S. (1993). Efficacy of carotid endarterectomy for asymptomatic carotid stenosis. New England journal of medicine, 328(4), 221-227 .

Horrocks, M. (2000). When should I reoperate for recurrent stenosis. In Carotid artery surgery: a problem-based approach (pp. 371-374). Harcourt Publishers Ltd, London, UK .

Linfante, I., Andreone, V., Akkawi, N., \& Wakhloo, A. K. (2009). Internal carotid artery stenting in patients over 80 years of age: Single - center experience and review of the literature. Journal of Neuroimaging, 19(2), 158-163 .

Mas, J.-L., Trinquart, L., Leys, D., Albucher, J.-F., Rousseau, H., Viguier, A., Bossavy, J.-P., Denis 'B., Piquet, P., \& Garnier, P. (2008). Endarterectomy Versus Angioplasty in Patients with Symptomatic Severe Carotid Stenosis (EVA-3S) trial: results up to 4 years from a randomised, multicentre trial. The Lancet Neurology, 7(10), 885-892 .

Narins, C. R \& ‘.Illig, K. A. (2006). Patient selection for carotid stenting versus endarterectomy: a systematic review. Journal of vascular surgery, 44(3), 661-672.

Organ, N., Walker, P., Jenkins, J., \& Foster, W. (2008). 15 year experience of carotid endarterectomy at the Royal Brisbane and Women's Hospital: outcomes and changing trends in management. 
European Journal of Vascular and Endovascular Surgery, 35(3), 273-279 .

Ouriel, K., Yadav, J., \& Green, R. M. (2004). Standards of practice: carotid angioplasty and stenting. Journal of vascular surgery, 39(4), 916-917 .

Ricotta, J. J., \& Malgor, R. D. (2008). A review of the trials comparing carotid endarterectomy and carotid angioplasty and stenting. Perspectives in vascular surgery and endovascular therapy, $20.308-299$ ،(3)

Sidawy, A., Zwolak, R., White, R., Siami, F., Schermerhorn, M., \& Sicard, G. (2009). Outcomes Committee for the Society for Vascular Surgery. Risk-adjusted 30day outcomes of carotid stenting and endarterectomy: results from the SVS Vascular Registry. J Vasc Surg, 49(1), 71-79.

Sidawy, A. N., Zwolak, R. M., White, R. A., Siami, F. S., Schermerhorn, M. L., Sicard, G. A., \& Surgery, O. C. f. t. S. f. V. (2009). Risk-adjusted 30-day outcomes of carotid stenting and endarterectomy: results from the SVS Vascular Registry. Journal of vascular surgery, 49(1), 71-79.

Tu, J. V., Hannan, E. L., Anderson, G. M., Iron, K., Wu, K., Vranizan, K., Popp, A. J., \& Grumbach, K. (1998). The fall and rise of carotid endarterectomy in the United States and Canada. New England journal of medicine, 339(20), 1441-1447 .

van der Vaart, M. G., Meerwaldt, R., Reijnen, M. M., Tio, R. A., \& Zeebregts, C. J. (2008). Endarterectomy or carotid artery stenting: the quest continues. The American journal of surgery, 195 (2) .269-259 


\title{
مقارنة تحليلية لنتائج استئصال باطنة الثريان السباتي وتركيب الدعامات في علاج الضيق السباتي الشرياني
}

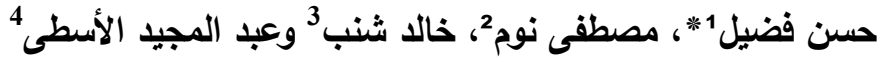

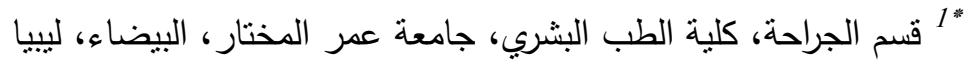

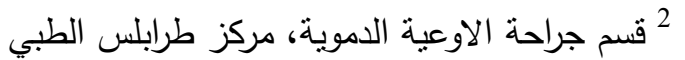

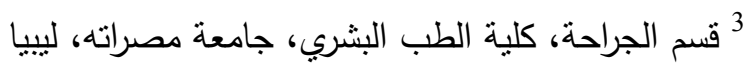 \\ 4 قسم الجراحة، مركز طرابلس الطبي
}

تاريخ الاستلام: 24 سبتمبر 2019 / تاريخ القبول:30134:13434 ديسمبر 2019 https://doi.org/10.54172/mjsc.v34i4.134:Doi

المستخلص: ضيق الثرايين السباتية هو سبب رئيس للجلطات المخية (20\%) والتي تكون دائما مصحوبة بمعدل تمرض عالٍ ووفيات مرتفعة. العلاج الرئيس هو بواسطة إجراء الجراحة للضيق الثرياني أو بالأشعة التداخلية ووضع دعامات للشريان السباتي. في هذه الدراسة تم مراجعة خبرة ونتائج 3 سنوات من علاج الضيق السباتي بواسطة الطريقتين. تهدف الدراسة إلى معايرة ومقارنة

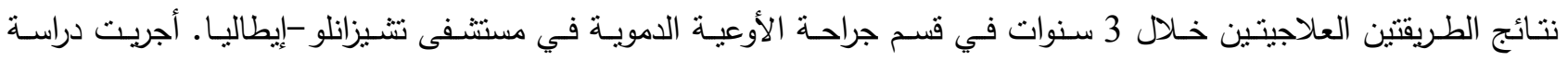
استقصائية لعدد 302 مريض (151 مريضاً لكل طريقة علاج). وأجريت مقارنات إحصائية لتوضيح فاعلية كل تدخل علاجي. O.R: 0.556; 95\% C.I; 0.349- ) حيث كان المعدل الزمني للتدخل العلاجي أعلى بوضوح في مجموعة التدخل الجراحي 0.886, P: 0.014 ولكن النجاح حقق في جميع الحالات والذي حقق في 91.3\% من حالات العلاج بالأشعة التداخلية والدعامات. الجلطات المخية التي حدثت حول العملية كانت غير مهمة للطريقتين. أما الجلطات العابرة المؤقتة كانت أكثر أهمية في حالات التدخل الإشعاعي والدعامات (O.R: 7.292, 95\% C.I; 1.150- 45.856, P: 0.032) إلا إن معظم الحالات تحسنت. إصابة الأعصاب الجمجمية كانت من المضاعفات المحددة للتنخل الجراحي (11.9\%). أما رجوع الضيق السباتي فكان فقط في مجموعة التدخل الإشعاعي والدعامات (2.9\%) مع (O.R: 0.493, 95\% C.I; 0.104- 2.345, P: 0.410). كلا الطريقتين فعال ومنوازٍ في نتائج علاج الضيق السباتي الشرياني.

الكلمات المفتاحية: الجلطة الدماغية، ضيق الشريان السباتي، التدخل الجراحة للشريان السباتي (CEA)، تركيب دعامة للشريان السباتي (CAS). 